\title{
An Overview of the Aviation Industry in India with Special Emphasis on Privatization
}

\author{
Pavithra Kumari* \& P. S. Aithal** \\ *Research Scholar, College of Management and Commerce, Srinivas University, Mangalore- \\ 575001, India \\ ORCID: https://orcid.org/0000-0003-4541-4242,E-mail: pavithrakumarishetty@gmail.com \\ **Professor, College of Management \& Commerce, Srinivas University, Mangalore - 575001, \\ India \\ ORCID: https://orcid.org/0000-0002-4691-8736; E-mail: psaithal@,gmail.com
}

Area of the Paper: Business Management.

Type of the Paper: Research Case Study.

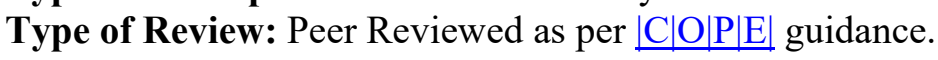

Indexed In: OpenAIRE.

DOI: $\underline{\text { http://doi.org/10.5281/zenodo. }}$

Google Scholar Citation: IJCSBE.

How to Cite this Paper:

Pavithra Kumari \& Aithal P. S. (2020). An Overview of the Aviation Industry in India with Special Emphasis on Privatization. International Journal of Case Studies in Business, IT, and Education (IJCSBE), 4(2), 220-228. DOI: http://doi.org/10.5281/zenodo.

International Journal of Case Studies in Business, IT and Education (IJCSBE)

A Refereed International Journal of Srinivas University, India.

(C) With Authors.

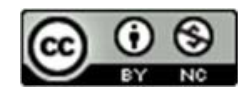

This work is licensed under a Creative Commons Attribution Non-Commercial 4.0 International License subject to proper citation to the publication source of the work.

Disclaimer: The scholarly papers as reviewed and published by the Srinivas Publications (S.P.), India are the views and opinions of their respective authors and are not the views or opinions of the S.P. The S.P. disclaims of any harm or loss caused due to the published content to any party. 


\title{
An Overview of the Aviation Industry in India with Special Emphasis on Privatization
}

\author{
Pavithra Kumari* \& P. S. Aithal** \\ *Research Scholar, College of Management and Commerce, Srinivas University, Mangalore- \\ 575001, India \\ ORCID: https://orcid.org/0000-0003-4541-4242, E-mail: pavithrakumarishetty@gmail.com \\ **Professor, College of Management \& Commerce, Srinivas University, Mangalore - 575001, \\ India \\ ORCID: https://orcid.org/0000-0002-4691-8736; E-mail: psaithal@gmail.com
}

\begin{abstract}
Aviation industry in India is presently an expeditious growing industry in India visually perceived according to the report in the last three years. So, India is well-known as the third largest domestic aviation market in the world and is foreseen to be the third largest air passenger market by the end of 2024. To work toward the requirements of the flyers, Government of India is working toward incrementing the number of airports. In 2019, India is reported to have 103 operational airports, with a considerable increase in the airplanes too. The Indian government has plans to invest more to develop the aviation industry with various strategies. Although tremendous achievements are seen recently, still more gaps in development have to be filled. With the increased demand in air travel, India's aviation industry by 2038 might need 2,380 new commercial airliners.
\end{abstract}

Keywords: Aviation industry, Airports, Air travel, Developmental strategy in aviation.

\section{INTRODUCTION :}

Globalization has topped as the key mechanism in the development of tourism, which has stepped in almost all areas like promotion of products, job enhancement, health sector and tourism. We witness the huge connectivity in the International markets in the present situation. This has marked the history in the aviation market. India currently is found to be the $9^{\text {th }}$ largest in aviation Industry, which is managing 41 million International passengers and 121 million national passengers. This owes to the fact that India is operating more than 85 International airlines with more than 40 countries [1]. Discussing the Industry of Aviation, it is understood that it has presently become the essential link for national and International travel and trade, which was once the elitist activity due to the cost. Hence aviation industry is especially important, for the economic development of the Nation because of the opportunity to increase business activity.

\section{OBJECTIVES \& METHODOLOGY :}

The main objectives of this paper are:

1. Understand the functioning of aviation industry in India.

2. To know the growth and development of civil aviation in India

3. To make ABCD analysis of PPP model

4. The contribution of the PPP model towards the future growth of aviation industry.

\section{AVIATION INDUSTRY IN INDIA :}

The history of Indian Aviation states back to 1912, December, when the first domestic flight flew between Karachi and Delhi. It commenced when the Indian Air facilities collaborated with the UK predicated imperial airways as an extension of London Karachi flight of the Imperial Airways. Hence three years the provision commenced with the designation of Tata Sons Ltd, the first Indian airline from Karachi and Madras. There was no backing from the Indian government [2].

In 1953, under the purview of the Indian Government Indian Airlines served the domestic civil aviation. During independence time, 9 air convey companies carried air cargo and the passengers within India. In 1948, the 
Indian regime and Air India together set up a company. Till the mid of 1990's government possessed airlines controlled Indian aviation industry. In 1990, the government of India implemented the open-sky policy and followed the liberalization rules. This paved the road to expeditious transformation in aviation industry.

If we analyze the market size of the aviation industry in India, it is seen that the passenger traffic rated at 341.05 million in fiscal year 2016. The compound yearly growth rate of 11.13 percent in the course of 2016 to 2020 . As per the report, the air traffic increased at a compound annual growth rate of $5.32 \%$ from the fiscal year 2016 to 2020 . It is assumed to reach to $7.27 \%$ in 2023 . The aircraft movement increased in the rate of $9.83 \%$ in domestic aircraft and $3.57 \%$ in international aircraft from FY16 to FY20.

Hence this development required a need of extra infrastructure, hence, in 2019, India had 103 operational airports. More airplanes operating in the sector is also a rising demand. With the increase in the infrastructure, the investment also was demanded. So according to the statistics produced by the Department for Promotion of the Industry and Internal Trade (DPIIT) [2], Overseas Direct Investment grown up to US\$2.75 billion amidst April 2000 and March 2000. The regime has promoted 100\% FDI under the automatic route in scheduled air travel facilities, regional air travel service and national scheduled passenger airline. This venture is assumed to reach 35,000 crores in the subsequent four years. So, it is planned by the government of India, to invest US\$ of 1.83 billion to develop the airport infrastructure along with the aviation navigation services by 2026 .

\section{RELATED WORK :}

A scholarly journal is a journal that contains papers written by experts in a specific area of study.

It contains authoritative information and may include extensive records of research, data, overviews, expert opinions on topics or topics. Table 1 lists a number of key academic publications and issues related to various sectors of the airport industry and its operations.

Table 1: Publications by various scholars on various Airport issues

\begin{tabular}{|l|l|l|l|}
\hline $\begin{array}{l}\text { Sl. } \\
\text { No. }\end{array}$ & Area & Issues & Reference \\
\hline 1 & $\begin{array}{l}\text { Aviation } \\
\text { industry }\end{array}$ & $\begin{array}{l}\text { Aimed to encourage PPP model in } \\
\text { India for the futuristic growth of } \\
\text { airports. }\end{array}$ & Viswanath A. et al. (2008) [3] \\
\hline 2 & Process & $\begin{array}{l}\text { A current scenario of aviation } \\
\text { industry in India. }\end{array}$ & Anubhav Singh, (2016) [4] \\
\hline 3 & Strategy & $\begin{array}{l}\text { Airbus A380-800, its role as full- } \\
\text { service network carrier's } \\
\text { commercial operations and its } \\
\text { design of route network. }\end{array}$ & Glenn Baxter, et al. (2018) [5] \\
\hline 4 & $\begin{array}{l}\text { Service } \\
\text { Quality }\end{array}$ & $\begin{array}{l}\text { Study on service qualities } \\
\text { provided in different air ports in } \\
\text { India }\end{array}$ & Ipseeta Satpathy, et al. 2017 [6] \\
\hline 5 & Privatization & $\begin{array}{l}\text { Study made to know that the } \\
\text { privatization adds financial value } \\
\text { to the economy. Hans-Arthur Vogel, (2011) [7] }\end{array}$ & Social, Economic \\
\hline 6 & Strategy & $\begin{array}{l}\text { Discovering the Socian } \\
\text { and Technical Condition of } \\
\text { Indian Aviation Industry. }\end{array}$ & Ashutosh Kolte, et al. (2009) [8] \\
\hline 7 & $\begin{array}{l}\text { Aviation } \\
\text { industry }\end{array}$ & $\begin{array}{l}\text { PPP model development. A } \\
\text { perspective for infrastructure } \\
\text { development in an airport. }\end{array}$ & Sambrani, V. N. (2014) [9] \\
\hline 8 & Strategy & $\begin{array}{l}\text { In a service-oriented sectors } \\
\text { Indian Aviation Industry is } \\
\text { becoming economically growing } \\
\text { industry. Anuradha Yadav. (2013) [10] }\end{array}$ & \\
\hline
\end{tabular}


International Journal of Case Studies in Business, IT, and Education (IJCSBE), ISSN: 2581-6942, Vol. 4, No. 2, November 2020

\begin{tabular}{|c|c|c|c|}
\hline 9 & Strategy & $\begin{array}{l}\text { Information Communication } \\
\text { Technologies playing major role } \\
\text { in tourism. }\end{array}$ & Deepthi Shanker. (2008) [11] \\
\hline 10 & $\begin{array}{l}\text { Aviation } \\
\text { industry }\end{array}$ & $\begin{array}{l}\text { Implementing the PPP model to } \\
\text { elongate subways. }\end{array}$ & Soliño, A. S. et al. (2009) [12] \\
\hline 11 & Perception & $\begin{array}{l}\text { Adaptation of passengers' } \\
\text { perceptions of airport for } \\
\text { improvement of service quality. }\end{array}$ & Jin-Woo, P. et al. (2011) [13] \\
\hline 12 & $\begin{array}{l}\text { Aviation } \\
\text { industry }\end{array}$ & $\begin{array}{l}\text { Adoption of PPP model for the } \\
\text { Greenfield airport development. }\end{array}$ & Rajan, T. A. et al. (2009) [14] \\
\hline 13 & $\begin{array}{l}\text { Aviation } \\
\text { industry }\end{array}$ & $\begin{array}{l}\text { Investment opportunities in the } \\
\text { next phase of development } \\
\text { through privatization of airports } \\
\text { in India. }\end{array}$ & Raghunath, S. (2010) [15] \\
\hline 14 & Privatization & $\begin{array}{l}\text { Economic regulation for healthy } \\
\text { competition amongst government } \\
\text { owned, PPP-based \& Private } \\
\text { Airports in India. }\end{array}$ & D.P. Singh, et al. (2015) [16] \\
\hline 15 & Perception & $\begin{array}{l}\text { PPP model is more suitable for } \\
\text { public service sector in terms of } \\
\text { cost saving rather than another } \\
\text { sector. }\end{array}$ & Riess, Armin. (2005) [17] \\
\hline 16 & Infrastructure & $\begin{array}{l}\text { PPP model concentrate more on } \\
\text { infrastructure development and } \\
\text { help to attract more tourist. }\end{array}$ & Suat Teker, et al. (2012) [18] \\
\hline 17 & Infrastructure & $\begin{array}{l}\text { To provide more facility to the } \\
\text { customer PPP model helpful to } \\
\text { work with AAI. }\end{array}$ & Sharad Kumar (2018) [19] \\
\hline 18 & $\begin{array}{l}\text { Airline } \\
\text { Operator }\end{array}$ & $\begin{array}{l}\text { Involvement of private sector } \\
\text { operators on airport platform help } \\
\text { the airlines to focus on core } \\
\text { business. }\end{array}$ & $\begin{array}{l}\text { Carlos Oliveira Cruz, et al. (2011) } \\
\text { [20] }\end{array}$ \\
\hline 19 & $\begin{array}{l}\text { Aviation } \\
\text { Industry }\end{array}$ & $\begin{array}{l}\text { PPP of Airport. Generates } 2 \\
\text { sources of Revenue i.e. } \\
\text { aeronautical and } \\
\text { aeronautical. }\end{array}$ & Eduardo Engel, et al. (2018) [21] \\
\hline 20 & $\begin{array}{l}\text { Aviation } \\
\text { Industry }\end{array}$ & $\begin{array}{l}\text { Private sector will be capable of } \\
\text { more financing and investing in } \\
\text { order to improve the service } \\
\text { efficiency. }\end{array}$ & Tae H. Ouma, et al. (2006) [22] \\
\hline 21 & $\begin{array}{l}\text { Business } \\
\text { Strategy }\end{array}$ & $\begin{array}{l}\text { Applying ABCD Model for a } \\
\text { successful Business Model. }\end{array}$ & Aithal, P. S. (2016) [25] \\
\hline
\end{tabular}

\section{GOVERNMENT PROGRAMS TO DEVELOP THE AVIATION INDUSTRY :}

The growth of the aviation Industry in India was tremendously in rise both economically and socially. With the increase in the air flyers, the economic growth was also witnessed. Development and investments in the industry was in increase, within these recent years. In 2019, AAI set up plans to start the first three water airports in Andaman \& Nicobar. It was additionally observed in 2020, January, just afore the outbreak of COVID-19, IndiGo was promulgated to be the first Indian air carrier to increase the aircraft fleet size of 250 planes, which was venerated to operate 1500 flights per day. With the increase in the aircrafts, Indian Aviation industry had to invest US\$150 million [23] for the aircraft maintenance, repair and Overhaul unit to render 
quality service to the customers in December 2019. This service was completely exempted from the customs and countervailing duties.

In November 2019 the Competition Commission of India permitted Adani Properties private Limited to acquire the shareholding in Mumbai International Airport Limited. To cater to all these requirements of the Aviation Industry, AAI has a long-term five-year plan, so to expand amenities and infrastructure at the airports, it invested nearly 25,000 crores. To develop Guwahati as an inter-regional hub and Agartala, Imphal and Dibrugarh as intra-regional hubs it also undertook a strategy to accomplish this. The services rendered by the aviation Industry was highly notes. In the year 2020, the air traffics was recorded to be 341.05 million [23] with the compound annual growth rate of 11.13 percent. National passenger circulation also added to this development by having 274.50 million in FY20 with 66.54 million and the compound growth rate of 5.01 percent. The international aircraft movement reached 2,155 thousand in FY20. So, to cater to these developments, there were 103 operational airports in India, which increased 190-200 in FY20. It was observed that It was also observed that air transport sector of India reached US\$2.75 billion in the middle of April 2000 and March 2020. The government has permitted 100 percent FDI under the automatic route in planned air transport service, regional air transport facility and national scheduled passenger airline. But the government approval is required for FDI over 49 percent. Aviation Industry of India is likely to witness Rs 35,000 crore (US\$ 4.99 billion) investment in the next four years. The aviation industry in India should witness a Rs 35,000 crores (US\$4.99 billion) investment over the next four years. For the expansion of airport infrastructure along with aviation navigation services, India's Government is also planning to invest US\$ 1.83 billion by 2026 .

Accordingly, Indian Government has taken many Initiatives to further develop the aviation industry. Under 'Lifeline Udan' an initiative by India's Government flights was operated for the transportation of essential medical cargo to distant parts of the country to support India's war against COVID-19. As of May 05, 2020, Air India, Alliance Air, IAF including private carriers operated 465 flights. The government also introduced 'Krishi Udan Scheme' both on national and international routes to aid farmers in transporting agricultural product and improving product value. This scheme was introduced in Union Budget 2020-21. Government of India is also promoting aircraft financing and leasing activities under the Union Budget 2019-20 to make Indian aviation market self-reliant. T0 develop the new greenfield airport in Hirasar, Gujarat, the Government of India In February 2019 sanctioned with an estimated investment of Rs 1,405 crore (US\$ 194.73 million). In January 2019, the Government of India was working on an overarching plan to promote domestic aircraft manufacturing and financing in the country. In January 2019, Government organized the Global Aviation Summit in Mumbai, which witnessed participation of over 1,200 delegates from 83 countries. In January 2019, the Government of India released its 2019 National Air Cargo Policy Overview that envisioned making Indian air cargo and logistics the most efficient, transparent and profitable across the globe by the end of the next decade.

The Regional Connectivity Scheme (RCS) is being rolled out. All these improvements made by the Government brought in lot of economic development. Hence Under the RCS-Udan program, about 34,74,000 passengers were carried and 335 routes were assigned in 2019, covering 33 airports (20 unserved, 3 underserved, 10 water aerodromes). In order to improve the promotion of the environment a great deal of work has been done. As a result, as of October 2019, 55 IAA airports have been reported as single-use plastic-free airport terminals. It was expected that India would have the most aircraft flying on its regular airlines by December 2019.

\section{ACHIEVEMENTS AFTER THE INITIATIVES TAKEN BY THE GOVERNMENT :}

With the various initiatives taken by the Government of India, huge promotions in the Aviation Industry was seen. So, the number of passengers flying increased to 34,74,000 in 335 routes, which covered 33 airports. In addition, to be environmentally friendly, close to 55 IAA airports reported single-use non-plastic airport terminals.

\section{FUTURE OF THE AVIATION INDUSTRY IN INDIA AFTER PRIVATIZATION :}

In order to avail flight facilities to the majority of the country's population who are unable to get the flight services due to economic constraints, the aviation industry need to tap several resources. This will cater to the 
$40 \%$ development. Industry stakeholders must also be engaged and collaborated with policymakers to implement effective and rational decisions that would stimulate India's civil aviation industry.

Should this strategy be pursued, India would reach the third largest aviation market by 2020. Expenditures by Indian travellers are projected to increase to 9.5 Lakh crore ( $\$ 136$ billion) by 2021 . The growing demand for air travel means that India will need 2,380 new commercial aircraft by 2038. This will promote the economy of the Nation indirectly and also will improve the standard of living of the people. This would position India as the third largest aviation market by 2020. If the economy moves forward and ends the current global pandemic, Indian travellers should grow to Rs. 9.5 lakh. This may necessitate an increase in demand for air transport. This means that India needs about 2,380 new commercial aircraft by 2038 [24].

\section{ABCD ANALYSIS OF PPP MODEL OF AVIATION IN INDIA:}

$\mathrm{ABCD}$ analysis is a framework for qualitative and quantitative analysis of systems, concepts, technology, ideas, and strategies developed in the year 2015 [25-29]. This framework suggests identifying advantages (A), benefits (B), constraints (C), and disadvantages (D) of the system. Here, we have identified advantages, benefits, constraints, and disadvantages of PPP model in India [30].

Table 2: ABCD analysis based on PPP model

\begin{tabular}{|c|c|c|c|c|c|}
\hline SI. No & Organization & Customer & Employees & Society & Cargo sector \\
\hline Advantages & $\begin{array}{l}\text { 1. Airport } \\
\text { expansion } \\
\text { 2. Increased } \\
\text { infrastructure. } \\
\text { 3. More revenue } \\
\text { generation. } \\
\text { 4. Competent to } \\
\text { investment. } \\
\text { 5. Increased } \\
\text { demand for non- } \\
\text { aeronautical } \\
\text { service. }\end{array}$ & $\begin{array}{l}\text { 1. To provide } \\
\text { service with } \\
\text { international } \\
\text { standards. } \\
2 \text {. Faster } \\
\text { service to } \\
\text { save time. } \\
\text { 3. Handling } \\
\text { of baggage } \\
\text { with due } \\
\text { care. }\end{array}$ & $\begin{array}{l}\text { 1. Better } \\
\text { training. } \\
\text { 2. Support of } \\
\text { updated } \\
\text { technology. }\end{array}$ & $\begin{array}{l}\text { 1. Economic } \\
\text { development. } \\
\text { 2.Increased } \\
\text { revenues under } \\
\text { the } \\
\text { International } \\
\text { Service } \\
\text { Standard. } \\
\text { 3.Community } \\
\text { development. }\end{array}$ & $\begin{array}{l}\text { 1. Increased } \\
\text { cargo business. } \\
\text { 2. Main } \\
\text { mechanism for } \\
\text { procurement. } \\
\text { 3. Faster } \\
\text { delivery of } \\
\text { cargo. } \\
\text { 4. Quality } \\
\text { storage system } \\
\text { for cargo. }\end{array}$ \\
\hline Benefits & $\begin{array}{l}\text { 1. Improvised } \\
\text { standard of } \\
\text { service. } 2 . \\
\text { Increased } \\
\text { passengers. } \\
\text { 3. Increased } \\
\text { airlines. } \\
\text { 4. Target of } \\
\text { more } \\
\text { destination. }\end{array}$ & $\begin{array}{l}\text { 1. Increased } \\
\text { customer } \\
\text { satisfaction. } \\
\text { 2. Increase in } \\
\text { number of } \\
\text { flyers. } \\
\text { 3.Comfortabi } \\
\text { lity in } \\
\text { airport. } \\
\text { 4. Good } \\
\text { facilities } \\
\text { provided. }\end{array}$ & $\begin{array}{l}\text { 1. Better } \\
\text { incentive to the } \\
\text { best performer. } \\
\text { 2. Standard } \\
\text { facility is } \\
\text { provided. } \\
\text { 3. Transportation } \\
\text { facilities on free } \\
\text { of cost. }\end{array}$ & $\begin{array}{l}\text { 1. Increased } \\
\text { employment } \\
\text { opportunities. } \\
\text { 2. Economic } \\
\text { development. } \\
\text { 3. More } \\
\text { educational } \\
\text { institutions. } \\
\text { 4. More CSR } \\
\text { activities. } \\
\text { 5.Flow in a } \\
\text { greater number } \\
\text { of tourists. }\end{array}$ & $\begin{array}{l}\text { 1. More } \\
\text { revenue. } \\
\text { 2. Economic } \\
\text { growth. }\end{array}$ \\
\hline Constraints & $\begin{array}{l}\text { 1.Unsafe } \\
\text { airports. } \\
\text { 2. Financial } \\
\text { constraints. } \\
\text { 3. Lack of } \\
\text { public support. } \\
\text { 4. Difficulty in } \\
\text { land acquisition }\end{array}$ & $\begin{array}{l}\text { 1.Rigid } \\
\text { policies. } \\
\text { 2. Security } \\
\text { threat. } \\
\text { 3. expensive } \\
\text { service. } \\
\text { 4. High } \\
\text { charge for } \\
\text { parking, }\end{array}$ & $\begin{array}{l}\text { 1. High work } \\
\quad \text { Load. } \\
\text { 2. Target. } \\
\text { 3. Low pay. } \\
\text { 4. High stress. }\end{array}$ & $\begin{array}{l}\text { 1. More } \\
\text { tourist. } \\
2 \text {. Limitation } \\
\text { of entry to the } \\
\text { terminal } \\
\text { building. } \\
\text { 3. Increased } \\
\text { cost of } \\
\text { advertisement }\end{array}$ & $\begin{array}{l}\text { 1. Increased } \\
\text { policies. } \\
2 \text {. High charge } \\
\text { for storage and } \\
\text { handling of } \\
\text { cargo. } \\
\text { 3. Too much } \\
\text { of restrictions } \\
\text { on cargo. }\end{array}$ \\
\hline
\end{tabular}




\begin{tabular}{|c|c|c|c|c|c|}
\hline & $\begin{array}{l}\text { for expansion of } \\
\text { the airport. } \\
\text { 5. Government } \\
\text { Policies. }\end{array}$ & $\begin{array}{l}\text { facilities and } \\
\text { other utility } \\
\text { services. } \\
5 \text {. Fines to } \\
\text { the customer. }\end{array}$ & & $\begin{array}{l}\text { \& rents of } \\
\text { shops. } \\
\text { 4. Gap } \\
\text { between the } \\
\text { public and } \\
\text { company. }\end{array}$ & \\
\hline $\begin{array}{l}\text { Disadvantag } \\
\text { es }\end{array}$ & $\begin{array}{l}\text { 1. Increase in } \\
\text { unsafe flying. } \\
\text { 2. Decrease in } \\
\text { development of } \\
\text { the airport. } \\
\text { 3. Lack of } \\
\text { public support } \\
\text { 4. Political } \\
\text { interference. } \\
\text { 5. Too much } \\
\text { government } \\
\text { interference. } \\
\text { 6. Rotation of } \\
\text { employees. } \\
\text { 7. Lack of } \\
\text { previous } \\
\text { experience in } \\
\text { handling } \\
\text { airports. }\end{array}$ & $\begin{array}{l}\text { 1. } \\
\text { Aggression } \\
\text { behavior of } \\
\text { employees. } \\
2 \text {. Too } \\
\text { expensive } \\
\text { service. } \\
3 \text {. Not } \\
\text { reachable to } \\
\text { the } \\
\text { economically } \\
\text { poor people. } \\
\text { 4.Strict } \\
\text { custom } \\
\text { policies. }\end{array}$ & $\begin{array}{l}\text { 1. Work pressure. } \\
\text { 2. Less human } \\
\text { resource. } \\
\text { 3. Stringent } \\
\text { policies. }\end{array}$ & $\begin{array}{l}\text { 1. Western } \\
\text { influence on } \\
\text { the culture. } \\
2 . \text { Conflict of } \\
\text { interest } \\
\text { between public } \\
\text { and } \\
\text { organization. }\end{array}$ & $\begin{array}{l}\text { 1.Increased air } \\
\text { traffic. } \\
\text { 2. Too much } \\
\text { congestion in } \\
\text { cargo airport. } \\
\text { 3. Security } \\
\text { threat. }\end{array}$ \\
\hline
\end{tabular}

\section{CONCLUSION :}

(1) There are currently 91 international carriers in India, including 5 Indian carriers and 86 foreign carriers, reflecting the development of the aviation industry in India. With this connection with major countries of the world, the revenue passenger Kilometer in domestic airline demand growth in 2018 was $18.6 \%$ [31] which is three time the global RPK growth of $6.5 \%$.

(2) IAA has 125 airports and runways out of a total of 464 , and manages about $78 \%$ of domestic passenger traffic and $22 \%$ of international passenger traffic. The cargo traffic share in promoting economy was higher as $68.5 \%$ [32] in International cargo and 31.5\% in domestic cargo traffic. Together with this the maintenance, repair is expected to grow annually.

(3) Major achievement like the IGI airport in Delhi enhances safety and efficient in air transport management service due to the advanced and highest air traffic control tower. Hence Indian aviation sector is the highest contributor to Indian economy being the contribution of GDP of \$72 [33].

(4) It contributes to the economy indirectly by promoting globalization, where the fliers increased to 79 million in 2010 to 158 million in 2017. This may increase in the coming years. It also supports 7.5 million employment and 6.2 million in tourism. The cargo market also shows largest in UAE. Where, Delhi and Mumbai contribute highest to cargo market. Government is also aware that the privatization will make the modification on structural change in service provided by the airport and economically viable and sound [34].

(5) As it was noted that the customers always demand greater service from the airport and airlines after spending money [35]. So, PP model is one of the best models to meet the needs of the customer in systematic way. There are lot of challenges for the aviation industry. Presently the pandemic faced globally will have a fall on the rise of the aviation industry. With the world bank support the aviation should bring strategies to sustain its growth. However, the competitiveness of the Travel and Tourism may pressurize the tourism infrastructure to bring in more strategy for improvement.

\section{REFERENCE :}

[1] Shreeraj Hariharan, (2020) https://www.slideshare.net/shreerajhariharan/poject-on-aviation-sector-in-India. 
Retrieved on 10/09/2020.

[2] Indian Aviation Industry, Aviation Industry in India, Aviation Sector, Aviation Industry, Aviation Industry India [Internet]. Indianmirror.com. Available from: https://www.indianmirror.com/indianindustries/aviation.html.

[3] Viswanath A. and C. Jeevan Kumar. (2008). Building Infrastructure Through PPP Model: Policy Lessons From RGIA. Indian journal of Public Administrationl, 54(3), 587-594.

[4] Anubhav Singh,(2016). A study of Current Scenario of Aviation Sector in India. International Journal of Innovative Knowledge Concepts, 2(4), 92-98.

[5] Baxter Glenn, Panarat Srisaeng, Graham Wild (2018). The role of the airbus A380-800 aircraft in a fullservice network airline's commercial operations and route network design: the case of Thai airways international. Aeronautics and Aerospace Open Access Journal, 2(4), 223-233.

[6] Satpathy Ipseeta, BCM Patnaik, Sharad Kumar, (2017). Indian aviation industry: An overview. International Journal of Academic Research and Development, 2(6), 802-805.

[7] Vogel Arthur - Hans, (2011). Do privatized airports add financial value?: Research in Transportation Business \& Management, 1(1), 15-24.

[8] Kolte Ashutosh, Balkrishan V. Sangvikar, Komal Tilak Shettigar, Kevin Francis Joy, (2019). Exploring the Socio-Economic and Technological Situation of Indian Aviation Industry. Academy of Marketing Studies Journal, 23(3), 1-8.

[9] Sambrani, V. N. (2014). PPP from Asia and African perspective towards infrastructure development: A case study of Greenfield Bangalore International Airport, India.Procedia-Social and Behavioral Sciences, 157(2), 285-295.

[10] Anuradha Yadav, (2013). Indian Aviation Sector: As a Growing Service Sector in Indian Economy. International Journal of Science and Research, 4(11), 766-768.

[11] Shanker, D. (2008). ICT and Tourism: Challenges and Opportunities. In Proceedings of the International Conference on Tourism in India-Challenges Ahead, Indian Institute of Management Kozhikode (pp. 5058).

[12] Soliño, A. S., \& Vassallo, J. M. (2009). Using public-private partnerships to expand subways: MadridBarajas international airport case study. Journal of Management in Engineering, 25(1), 21-28.

[13] Woo - Jin, Park \& Se-Yeon, Jung. (2011). Transfer passengers' perceptions of airport service quality: a case study of Incheon International Airport. International Business Research, 4 (3), 75-82.

[14] Rajan Thillai A., Sheetal Sharad \& Sidharth Sinha. (2009). PPP in Greenfield airport development: a case study of Cochin international airport limited. Policy, Finance and Management for Public-Private Partnerships, CH-7, 97-122.

[15] Raghunath, S. (2010). Airport privatisation in India: Investment opportunities in the next phase of development. Journal of Airport Management, 4(3), 235-251.

[16] Singh D.P., Narendra N. Dalei \& T.B. Raju. (2015). Airport Privatization and Economic Regulation: An Indian Experience. International Journal of Multidisciplinary Research and Development, 2(5), 414-418.

[17] Riess Armin, (2005). Is the PPP model applicable across sectors? European Investment Bank (EIB) papers, 10(2), 11-20.

[18] Teker Suat, \& Dilek Teker, (2012). Tourism Projects Financing: A Public-Private-Partnership Model. Business Management Dynamics, 2(5), 05-11.

[19] Kumar Sharad, (2018). Customer Satisfaction of Service Qualities Provided in Different Airports in India. KIIT Journal of Management, 15(1/2), 302-303.

[20] Cruz Carlos Oliveira, \& Rui Cunha Marques, (2011). Contribution to the study of PPP arrangements in 
airport development, management and operation. Transport Policy-Elsevier, 18(2), 392-400.

[21] Engel Eduardo, Ronald Fischer, \& Alexander Galetovic, (2018). The joy of flying: Efficient airport PPP contracts. Transportation research part B-Elsevier, 114, 131-146.

[22] Oum Tae H, Nicole Adler, \& Chunyan Y, (2006). Privatization, corporatization, ownership forms and their effects on the performance of the world's major airports. Journal of Air Transport Management, 12(3), 109-121.

[23] India, \& Industry, I. (2020). Indian Aviation Industry, Aviation Sector in India, About, Analysis. Ibef.org. Retrieved 10 August 2020, from https://www.ibef.org/industry/indian-aviation.aspx.

[24] Indian Aviation Industry (2020). Aviation Industry in India, Aviation Sector, Aviation Industry, Aviation Industry India [Internet]. Indianmirror.com. Available from: https://www.indianmirror.com/indianindustries/aviation.html.

[25] Aithal P. S., (2016). Study on ABCD Analysis Technique for Business Models, business strategies, Operating Concepts \& Business Systems. International Journal in Management and Social Science, 4(1), 98-115.

[26] Aithal, P. S. (2016). Study on ABCD analysis technique for business models, business strategies, operating concepts \& business systems. International Journal in Management and Social Science, 4(1), 95-115.

[27] Shenoy, V., \& Aithal, P. S. (2016). ABCD Analysis of On-line Campus Placement Model. IRAInternational Journal of Management \& Social Sciences, (ISSN 2455-2267), 5(2), 227-244.

[28] Aithal, A., \& Aithal, P. S. (2017). ABCD Analysis of Task Shifting-An optimum Alternative Solution to Professional Healthcare Personnel Shortage. International Journal of Health Sciences and Pharmacy (IJHSP), 1(2), 36-51.

[29] Aithal, P. S. (2017). ABCD Analysis as Research Methodology in Company Case Studies. International Journal of Management, Technology, and Social Sciences (IJMTS), 2(2), 40-54.

[30] Kumari Pavithra, \& Aithal, P. S. (2020). Growth \& Fate Analysis of Mangalore International Airport - A Case Study. International Journal of Case Studies in Business, IT, and Education (IJCSBE), 4(2), 71-85.

[31] Aviation Industry in India, Aviation Sector Analysis, Growth [Internet]. Investindia.gov.in. Available from: https://www.investindia.gov.in/sector/aviation.

[32] Aviation Industry in India, Aviation Sector Analysis, Growth [Internet]. Investindia.gov.in.. Available from: https://www.investindia.gov.in/sector/aviation.

[33] Potential and Challenges of Indian Aviation [Internet]. Iata.org. Available from: https://www.iata.org/en/pressroom/pr/2018-09-04-02.

[34] Saraswati, S. K. (2001) Operating environment for a civil aviation industry in India, Journal of Air Transport Management, 7(2), 127-135.

[35] Himanshu Gupta (2017). Evaluating service quality of airline industry using hybrid best worst method and VIKOR. Journal of Air Transport Management, 68(C), 35-47.

$* * * * * * * * * * *$ 